\title{
Pembuatan Sistem Informasi "ETICK" (Event Registration and Ticketing) Menggunakan Framework Laravel
}

Rhesa Elian Nugroho

Fakultas MIPA, Program Studi D3 Teknik Informatika

Universitas Sebelas Maret

Email: rhesa.en@student.uns.ac.id

\section{Info Artikel}

\section{Kata Kunci :}

Sistem Informasi, Event,

Framework, Laravel

\section{Keywords :}

Information System, Event,

Framework, Laravel

\section{Tanggal Artikel}

Dikirim : 6 Oktober 2018

Direvisi : 26 Oktober 2018

Diterima : 5 November 2018

\section{Abstrak}

Penyelenggaraan sebuah event dari pengelola atau event organizerterkadang mengalami kendala dalam melakukan promosi dan mengumpulkan cukup banyak peserta disisi lain masyarakat juga perlu untuk mengetahui informasi lengkap mengenai event yang akan diselenggarakan. Untuk memenuhi kebutuhan tersebut maka perlu dirancang sebuah sistem informasi untuk mempermudah event organizer dan para peserta tersebut.

Tahap perancangan sistem ini meliputi pembuatan deskripsi use case diagram, activity diagram, sequence diagram, class diagram dan perancagan database. Implementasi dari sistem ini menggunakan Framework Laravel berbasis bahasa pemograman PHP.

Hasil dari penelitian ini telah dibuat aplikasi event registration and ticketing dengan fitur pengguna yang bertindak sebagai event organizer dalam aplikasi ini dapat melakukan unggah informasi dan promosi event yang akan diselenggarakan serta melakukan penjualan tiket elektronik. Sedangkan pengguna yang bertindak sebagai member dapat melakukan pembelian tiket pada aplikasi ini sehingga lebih mudah tanpa harus datang ke loket tiket.

\section{Abstarct}

Organizing an event from the event organizer sometimes constraints in doing promotions and amassed quite a number of participants on the other hand the community also need to know details of upcoming events is held. To fullfil this things it is necessary an information system designed to facilitate the event organizer and the participants.

This system design phase includes the creation of descriptions use case diagrams, activity diagrams, sequence diagrams, class diagrams and database designs. Implementation of this system using Laravel-based Framework PHP programming language.

Users who act as event organizer in this application can do post some information and promotional event which will be held as well as conducting electronic ticket sales. While users who act as members can purchase tickets on this application so much easier without having to come to the ticket counter. 


\section{PENDAHULUAN}

Kegiatan massal atau event seperti konser musik, pertunjukan seni, seminar, pameran dan lainnya merupakan salah satu daya tarik wisata yang mampu menjadi roda penggerak perekonomian suatu daerah. Event tersebut juga dapat digunakan sebagai sarana promosi daerah. Banyaknya eventyang diselenggarakan juga menjadi cermin adanya kreatifitas dan eksistensi dari suatu komunitas atau masyarakat dari daerah tersebut. Eventyang diselenggarakan dengan sukses juga akan memberikan kesan bahwa kawasan daerah tersebut aman, nyaman dan menarik untuk dikunjungi.

Dalam penyelenggaraan sebuah event, pengelola atau event organizer dari acara tersebut terkadang mengalami kendala dalam mengumpulkan cukup banyak peserta disisi lain masyarakat juga perlu untuk mengetahui informasi lengkap mengenai event yang akan diselenggarakan. Kemudian dalam pengelolaan peserta event tersebut sering kali masih menggunakan sistem manual dimana para peserta perlu datang ke tempat penyelenggara untuk mendapatkan tiket sebagai bukti keikutsertaannya. Pengelolaan peserta tersebut menjadi kurang efisien dan efektif dari segi waktu dan tempat bagi penyelenggara maupun calon peserta event.

Pengembangan sistem registrasi event dan pemesanan tiket online telah dikembangkan sesuai kegiatan yang diselenggarakan diantaranya yaitu sistem pemesanan tiket untuk sebuah pertandingan antar club sepak bola yang dikembangkan secara PHP native[1], sistem pemesanan tiket bus online berbasis web yang dikembangkan secara native [2], sistem pemesanan lagu yang menggunakan tiket secara online berbasis mobile web dan dikembangkan dengan framework $\mathrm{Cl}$ [3] dan sistem pemesanan tiket travel berbasis web yang dikembangkan dengan framework $\mathrm{Cl}$ [4].

Implementasi dari penelitian ini nantinya akan memanfaatkan framework terbaru yaitu framework laravel yang mana framework ini memudahkan developer dalam mendesain sebuah web event registration and ticketing. Terdapat beberapa fitur yang memudahkan developerpada frameworkini dengan kode program yang lebih singkat dan sederhana. Fitur dari migrations dan schema builder juga memudahkan developer dalam mendesain struktur database. Penggunaan framework Laravel sudah terbukti handal dalam membuat sistem reservasi seperti yang pernah digunakan oleh [5] untuk reservasi sebuah fasilitas dan oleh [6] untuk membuat sistem informasi manajemen laboratorium.

\section{METODOLOGI PENELITIAN}

Metodologi penelitian yang dilakukan dalam pengembangan aplikasi ini menggunakan metodologi penelitian Waterfall, yang terdiri dari beberapa tahap yaitu pertama software requirements gathering \& analysis, pada tahap ini dilakukan analisis kebutuhan pengguna maupun sistem melalui observasi dan survei di lapangan. Kedua adalah design, pada tahap ini dilakukan perancangan struktur database, kebutuhan fungisional sistem dan User Interface. Ketiga adalah pembuatan aplikasi, pada tahap ini dilakukan implementasi pembuatan database, front end, dan back end dari aplikasi. Yang keempat adalah testing program, pada tahap ini dilakukan pengujian untuk mengetahui apakah implementasi sudah sesuai dengan rancangan. Pada Gambar 1 disajikan alur proses bisnis dari aplikasi. Pernagkat lunak yang diperlukan dalam pembuatan sistem diantaranya Text Editor Sublime versi 3, DBMS MariaDB, Web Server Apache, PHP Versi 7. Dan Framework Laravel versi 5.4.

Dari ilustrasi alur proses bisnis Gambar 1, dapat dijelaskan bahwa terdapat tiga aktor utama dalam sistem yaitu Event Organizer, Member, dan Administrator. Ketiga aktor tersebut harus login sebelum melakukan aktifitas dalam sistem. Setelah Event Organizermendaftarkan event dengan memasukkan data yang lengkap sesuai ketentuan. Maka event akan tertampil pada halaman utama, sehingga member dapat memilih event yang akan dikunjungi. Member melakukan pemesanan tiket setelah memilih event, kemudian melakukan pembayaran melalui transfer bank. Setelah melakukan pembayaran, member harus melakukan konfirmasi pembayaran berdasarkan bukti transaksi. Administrator akan melakukan validasi transaksi apabila konfirmasi pembayaran telah dilakukan. Jika seluruh proses transaksi telah dipenuhi, maka member dapat mencetak e-tiket melalui sistem. 


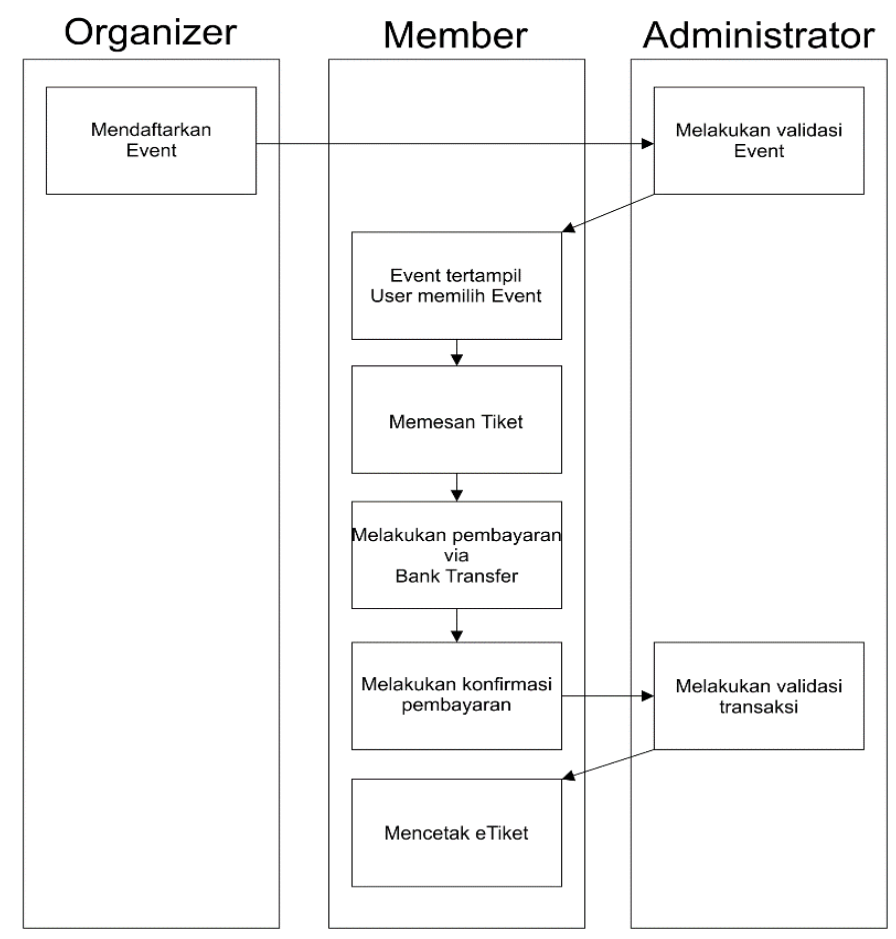

Gambar 1. Alur proses bisnis aplikasi "e-tick" (event registration and ticketing)

\section{HASIL DAN PEMBAHASAN}

Setelah aplikasi sistem informasi event registration and ticketing telah selesai dibangun, langkah selanjutnya yaitu melakukan pengujian fungsional aplikasi. Pengujian dilakukan dengan memasukkan data ke dalam sistem, data-data tersebut adalah data tentang event, harga tiket, pemesanan tiket yang kemudian akan diolah menjadi data informasi seperti elektronik tiket dan data hasil penjualan/pendapatan. Tampilan aplikasi front-end untuk event organizer dalam memasukkan data event dan tiket disajikan pada Gambar 2 dan Gambar 3. Hasil pendapatan dari event nantinya akan dapat dicetak melalui sistem dalam bentuk file PDF ditunjukan pada Gambar 4. Sedangkan tampilan front-end untuk member dalam melakukan pemesanan tiket ditunjukkan pada Gambar 5.

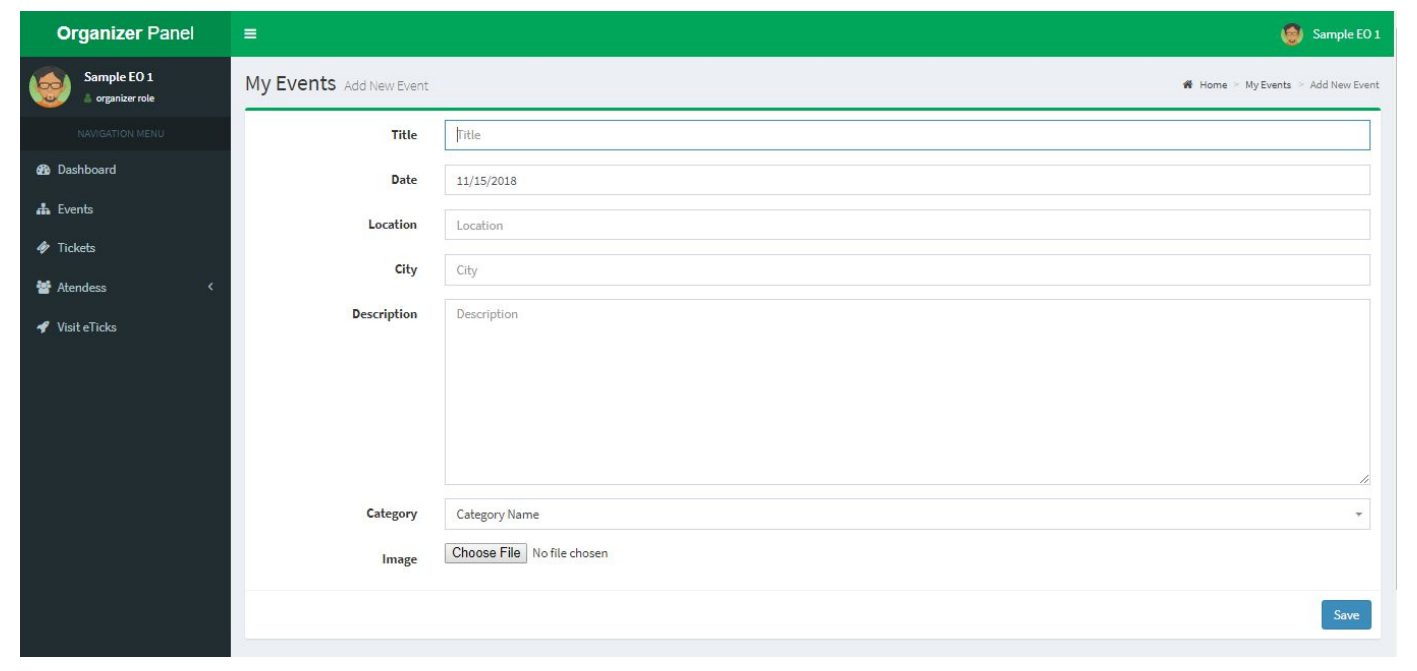

Gambar 2. User Interface kelola event untuk event organizer 


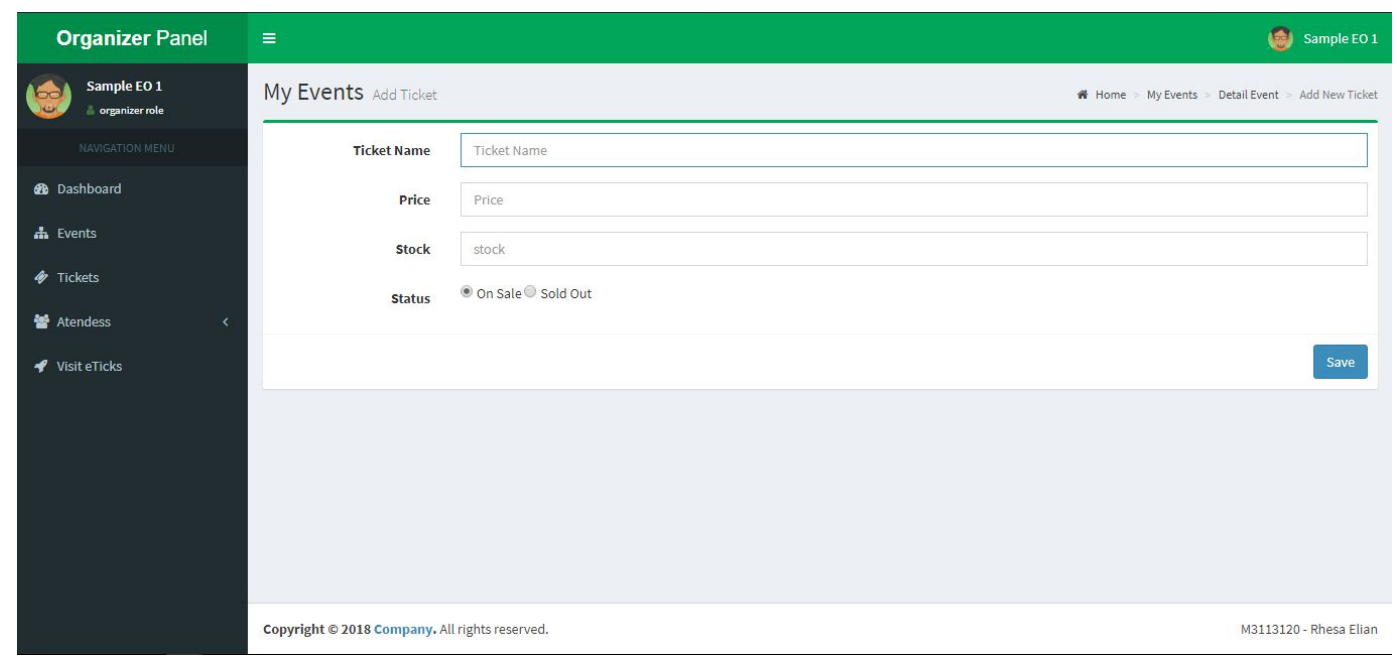

Gambar 3. User Interface kelola tiket untuk event organizer

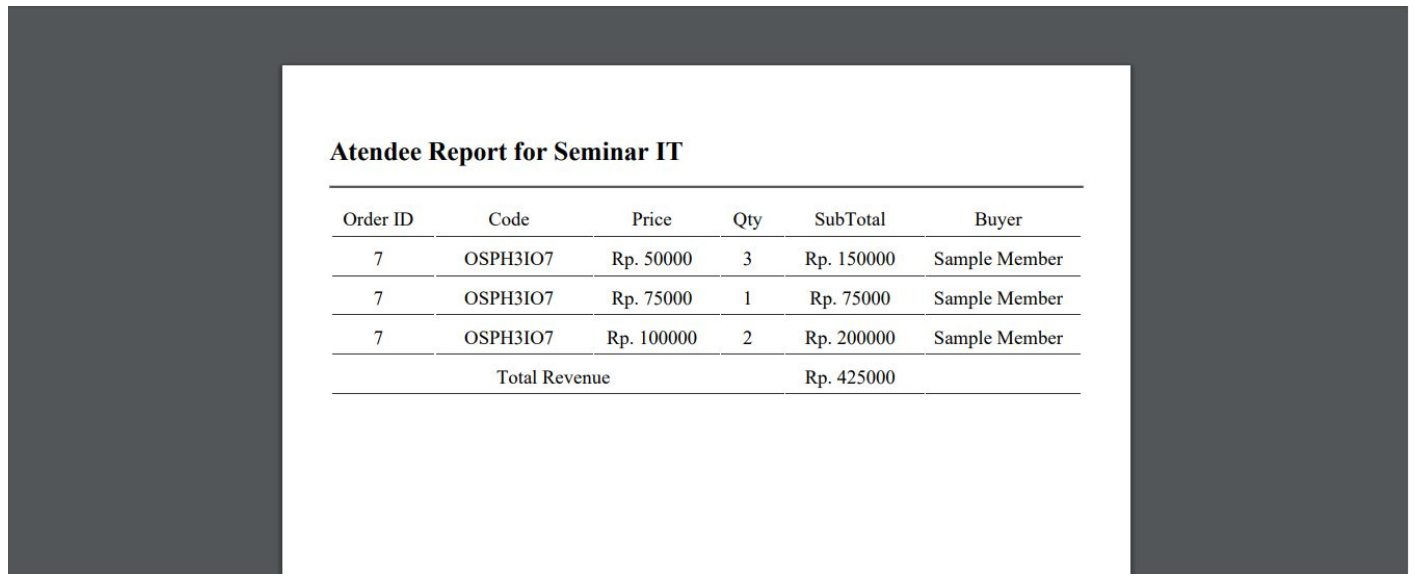

Gambar 4. Laporan hasil pemdapatan dari sebuah event dalam bentuk PDF

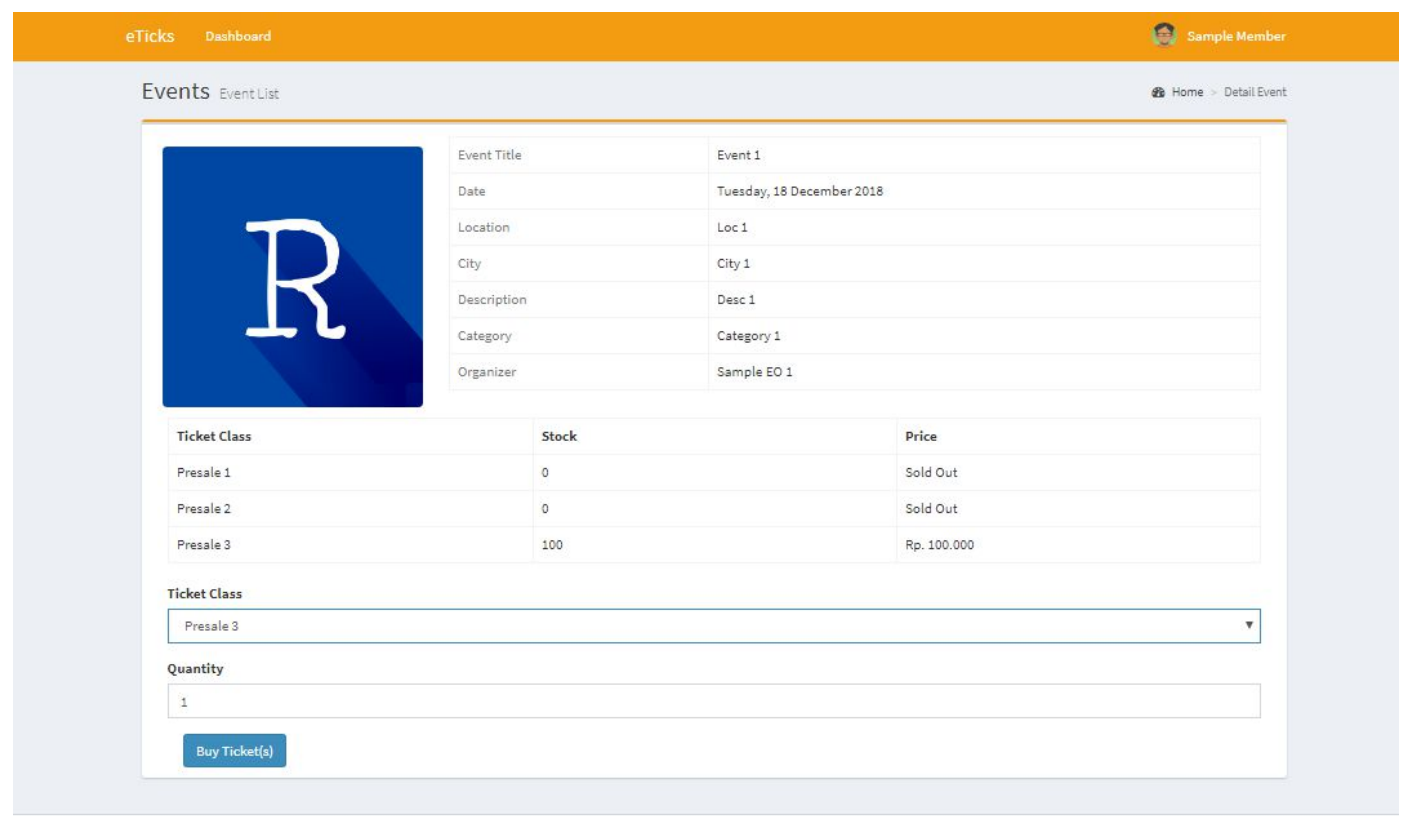

Gambar 5. User Interface pemesanan tiket event untuk member 
Pengujian juga dilakukan untuk fitur lainnya dalam aplikasi event registration and ticketing yang dilakukan dengan metode Black Box Testing dan hasilnya dirangkum dalam Tabel 1.

Tabel 1. Tabel Black Box Testing

\begin{tabular}{|c|c|c|c|c|}
\hline No & Fungsionalitas & Skenario & Indikator & Status \\
\hline 1. & $\begin{array}{l}\text { Registrasi event } \\
\text { organizer dan } \\
\text { member }\end{array}$ & $\begin{array}{ll}\text { a. } & \text { Menginput } \\
& \text { data event } \\
& \text { organizer } \\
& \text { ke dalam } \\
& \text { sistem } \\
\text { b. } & \text { Menginput } \\
& \text { data } \\
& \text { member ke } \\
\text { dalam } \\
\text { sistem }\end{array}$ & $\begin{array}{ll}\text { a. } & \begin{array}{l}\text { Data event } \\
\text { organizer }\end{array} \\
& \text { berhasil } \\
& \text { ditambahkan } \\
& \text { ke dalam } \\
& \text { sistem } \\
\text { b. } & \text { Data } \\
& \text { member } \\
& \text { berhasil } \\
\text { ditambahkan } & \text { ke dalam } \\
\text { sistem }\end{array}$ & Berhasil \\
\hline 2. & $\begin{array}{l}\text { Memasukkan data } \\
\text { kategori oleh } \\
\text { administrator }\end{array}$ & $\begin{array}{l}\text { Menginput data } \\
\text { kategori ke dalam } \\
\text { sistem }\end{array}$ & $\begin{array}{l}\text { Data kategori berhasil } \\
\text { ditambahkan ke dalam } \\
\text { sistem }\end{array}$ & Berhasil \\
\hline 3. & $\begin{array}{l}\text { Mengubah data } \\
\text { kategori oleh } \\
\text { administrator }\end{array}$ & $\begin{array}{l}\text { Memperbarui data } \\
\text { kategori yang ada } \\
\text { pada sistem }\end{array}$ & $\begin{array}{l}\text { Data kategori berhasil } \\
\text { diperbarui }\end{array}$ & Berhasil \\
\hline 4.. & $\begin{array}{l}\text { Menghapus data } \\
\text { kategori oleh } \\
\text { administrator }\end{array}$ & $\begin{array}{l}\text { Menghapus data } \\
\text { kategori yang ada } \\
\text { pada sistem }\end{array}$ & $\begin{array}{l}\text { Data kategori berhasil } \\
\text { terhapus }\end{array}$ & Berhasil \\
\hline 5. & $\begin{array}{l}\text { Menampilkan data } \\
\text { kategori oleh } \\
\text { administrator }\end{array}$ & $\begin{array}{l}\text { Menampilkan data } \\
\text { kategori yang ada } \\
\text { pada sistem }\end{array}$ & $\begin{array}{l}\text { Data kategori berhasil } \\
\text { ditampilkan }\end{array}$ & Berhasil \\
\hline 6. & $\begin{array}{l}\text { Mengubah status } \\
\text { event oleh } \\
\text { administrator }\end{array}$ & $\begin{array}{l}\text { Memperbarui status } \\
\text { event yang ada pada } \\
\text { sistem }\end{array}$ & $\begin{array}{l}\text { Data status event } \\
\text { berhasil diperbarui }\end{array}$ & Berhasil \\
\hline 7. & $\begin{array}{l}\text { Mengubah status } \\
\text { pesanan oleh } \\
\text { administrator }\end{array}$ & $\begin{array}{l}\text { Memperbarui status } \\
\text { pemesanan yang ada } \\
\text { pada sistem }\end{array}$ & $\begin{array}{l}\text { Data status } \\
\text { pemesanan berhasil } \\
\text { diperbarui }\end{array}$ & Berhasil \\
\hline 8. & $\begin{array}{l}\text { Memasukkan data } \\
\text { event oleh event } \\
\text { organizer }\end{array}$ & $\begin{array}{l}\text { Menginput data event } \\
\text { ke dalam sistem }\end{array}$ & $\begin{array}{l}\text { Data event berhasil } \\
\text { dimasukkan ke dalam } \\
\text { sistem }\end{array}$ & Berhasil \\
\hline 9. & $\begin{array}{l}\text { Mengubah data event } \\
\text { oleh event organizer }\end{array}$ & $\begin{array}{l}\text { Memperbarui data } \\
\text { event yang ada pada } \\
\text { sistem }\end{array}$ & $\begin{array}{l}\text { Data event berhasil } \\
\text { diperbarui }\end{array}$ & Berhasil \\
\hline 10. & $\begin{array}{l}\text { Menampilkan data } \\
\text { event oleh event } \\
\text { organizer }\end{array}$ & $\begin{array}{l}\text { Menampilkan data } \\
\text { event yang ada pada } \\
\text { sistem }\end{array}$ & $\begin{array}{l}\text { Data event berhasil } \\
\text { ditampilkan }\end{array}$ & Berhasil \\
\hline 11. & $\begin{array}{l}\text { Memasukkan data } \\
\text { tiket oleh event } \\
\text { organizer }\end{array}$ & $\begin{array}{l}\text { Menginput data tiket } \\
\text { ke dalam sistem }\end{array}$ & $\begin{array}{l}\text { Data tiket berhasil } \\
\text { dimasukkan ke dalam } \\
\text { sistem }\end{array}$ & Berhasil \\
\hline 12. & $\begin{array}{l}\text { Mengubah stock tiket } \\
\text { oleh event organizer }\end{array}$ & $\begin{array}{l}\text { Memperbarui data } \\
\text { stock tiket yang ada } \\
\text { pada sistem }\end{array}$ & $\begin{array}{l}\text { Data stock tiket } \\
\text { berhasil diperbarui }\end{array}$ & Berhasil \\
\hline 13. & $\begin{array}{l}\text { Memasukkan data } \\
\text { pemesanan oleh } \\
\text { member }\end{array}$ & $\begin{array}{l}\text { Menginput data } \\
\text { pemesanan ke dalam } \\
\text { sistem }\end{array}$ & $\begin{array}{l}\text { Data pemesanan } \\
\text { berhasil dimasukkan } \\
\text { ke dalam sistem }\end{array}$ & Berhasil \\
\hline
\end{tabular}




\begin{tabular}{|c|c|c|c|c|}
\hline No & Fungsionalitas & Skenario & Indikator & Status \\
\hline 14. & $\begin{array}{l}\text { Melakukan konfirmasi } \\
\text { pembayaran pesanan } \\
\text { oleh member }\end{array}$ & $\begin{array}{l}\text { Menginput data } \\
\text { pembayaran ke dalam } \\
\text { sistem }\end{array}$ & $\begin{array}{l}\text { Data pembayaran } \\
\text { berhasil dimasukkan } \\
\text { ke dalam sistem }\end{array}$ & Berhasil \\
\hline 15. & $\begin{array}{l}\text { Mencetak elektronik } \\
\text { tiket oleh member }\end{array}$ & $\begin{array}{l}\text { Mencetak elektronik } \\
\text { tiket dalam format } \\
\text { PDF }\end{array}$ & $\begin{array}{l}\text { Data pada elektronik } \\
\text { tiket berhasil dicetak } \\
\text { dalam format PDF }\end{array}$ & Berhasil \\
\hline 16. & $\begin{array}{l}\text { Mencetak hasil } \\
\text { pendapatan oleh } \\
\text { event organizer }\end{array}$ & $\begin{array}{l}\text { Mencetak data } \\
\text { pendapatan event } \\
\text { dalam format PDF }\end{array}$ & $\begin{array}{l}\text { Data pendapatan event } \\
\text { berhasil dicetak dalam } \\
\text { format PDF }\end{array}$ & Berhasil \\
\hline
\end{tabular}

Berdasar Tabel 1 telah dilakukan pengujian sistem informasi "etick" (event registration and ticketing) menggunakan metode Black Box Testing dengan cara melakukan pengujian terhadap setiap fungsionalitas sistem dan menghasilkan keluaran sesuai dengan rancangan.

\section{KESIMPULAN}

Hasil yang didapat yaitu telah berhasil dilakukan perancangan dan pembuatan Sistem Informasi “ETICK” (Event Registration and Ticketing) menggunakan framework laravel. Berdasarkan simulasi penggunaan sistem, aplikasi dapat digunakan sebagai sarana promosi eventdan media untuk melakukan pembelian tiket event sehingga lebih memudahkan para event organizer dan calon peserta.

\section{DAFTAR PUSTAKA}

[1] E. S. Soegoto and I. F. Siddiq, "Development of online ticket system at a football club in Bandung," in IOP Conf. Ser.: Mater. Sci. Eng. 407 012049, 2018.

[2] A. R. A. Rahmat and A. Octaviano, "Aplikasi Pemesanan Tiket Bus Berbasis Web (Studi Kasus Pada P0. Harapan Jaya)," Jurnal Informatika Universitas Pamulang, vol. 1, no. 1, pp. 1-11, 2016.

[3] A. N. Ari, G. P. Kusuma and H. P. Utomo, "Aplikasi Indonesia Musik Event Berbasis Mobile Web," in eProceeding of Applied Science : Vol.2, No.1, 2016.

[4] C. P. Wijaya, K. I. Satoto and R. R. Isnanto, "Perancangan Sistem Informasi Pemesanan Tiket Travel Berbasis Web," TRANSMISI, vol. 15, no. 2, pp. 80-86, 2013.

[5] N. P. Sari, D. Kurniadi and D. Irfan, "Sistem Informasi Reservasi Fasilitas Universitas Negeri Padang Berbasis Framework Laravel," Jurnal Vokasional Teknik Elektronika dan Informatika, vol. 6, no. 2, pp. 1-8, 2018.

[6] A. L. Yudanto, H. Tolle and A. H. Brata, "Rancang Bangun Aplikasi Sistem Informasi Manajemen Laboratorium Biomedik Fakultas Kedokteran Universitas Brawijaya," Jurnal Pengembangan Teknologi Informasi dan IImu Komputer, vol. 1, no. 8, pp. 628-634, 2017. 